http://dx.doi.org/10.12775/szhf.2016.057

\author{
ANDRZEJ J. Noras \\ Uniwersytet Śląski, Katowice, Polska \\ ANDRZEJ.NORAS@US.EDU.PL
}

\title{
Problem ugruntowania filozofii w doktrynie Hermanna Cohena
}

Ugruntowanie filozofii stanowi największy problem jej samej, a zatem można rozpocząć rozważania od stwierdzenia, że największym zadaniem filozofii jest ugruntowanie samej siebie. Zadanie to pozostaje w ścisłym związku z kilkoma kwestiami, spośród których należy wymienić przynajmniej dwie, a mianowicie (I) rozumienie doświadczenia oraz (II) rozumienie wzajemnej relacji filozofii i jej historii. Zarówno jedno, jak i drugie zagadnienie są bardzo złożone, warto jednak zacząć od pierwszego. Trzeba ponadto pamiętać, że w tle pojawia się tu jeszcze jeden problem, a mianowicie rozumienie nauki - i filozofii, bo dla neokantystów, a zwłaszcza neokantystów marburskich - filozofia jest bez wątpienia nauką.

Wydaje się, że kluczem do zrozumienia problemu ugruntowania na gruncie neokantyzmu jest rozumienie idealizmu. Przejście do analiz poświęconych rozumieniu idealizmu wymaga jednak zaakcentowania znaczenia elementu historycznego. Étienne Gilson kwestię tłumaczy następująco: „Kartezjusz ma wiele na usprawiedliwienie faktu, iż był sobą, nie ma jednak żadnego uspra- 
wiedliwienia kartezjanin"1. Chce zatem Gilson uświadomić historykowi filozofii i filozofowi jednocześnie, skoro historia filozofii stanowi integralną część filozofii, że jeśli dąży się do odnowienia jakiejś koncepcji filozoficznej, to nie wolno powielać zawartych w niej błędów. Niewątpliwie Gilson ma rację, wskazując na fakt, że neofilozofia musi uniknąć błędów zawartych w filozofii stanowiącej dla niej punkt wyjścia. Problem polega wszakże na tym, że neofilozofia jest neofilozofii nierówna. Kiedy na przykład reprezentanci neotomizmu pytali o konsekwencję w odczytywaniu myśli Tomasza z Akwinu, wówczas neokantyści walczyli o możliwość wykorzystania filozofii Kanta do rozwiązania piętrzących się przed nimi (przed filozofią) problemów. Odnowienie określonej filozofii neokantyści wiązali więc z zakwestionowaniem ortodoksji względem oryginału. Co więcej, wydaje się, że tu właśnie leży klucz do oceny neofilozofii.

Problem podejmuje Herbert Schnädelbach, ujmując go w kontekście relacji neokantyzmu do Kanta. Warto przytoczyć dłuższy fragment jego wypowiedzi, który brzmi:

[...] różnica między „-istą” a „neo-istą" polega na tym, że „neo-ista” przyjmuje za punkt wyjścia niemożliwość bezpośredniej kontynuacji myśli autora, do którego nawiązuje; stał się on dla niego historyczny, dlatego też dla "neo-isty” nie ma innej możliwości, jak swoją myśl uprawiać w jego „duchu”. Tym, co odróżnia neokantyzm od ruchu kantowskiego połowy dziewiętnastego stulecia, tak samo jak neoheglizm od właściwego heglizmu, jest - porządkując problem - świadomość historyczna, doświadczenie przełamania tradycji w taki sposób, że „powrót do...!” ma szansę tylko jako „wyjście poza...!”2.

Występująca tu zależność nie jest prosta i jednoznaczna, ale ujawnia zarazem dwie strony: wyjście poza filozofię stanowiącą oryginał i - w nawiązaniu do tego - problem ortodoksji. Neofilozofia, która próbuje zrozumieć mistrza dosłownie - przykładem jest tzw. filologia Kantowska w historii neokantyzmu - jest wprawdzie ortodoksyjna, ale trudno się w niej doszukiwać odpowiedzi na pytania nurtujące filozofów w czasach, kiedy powstaje. Można zatem uogólnić pojawiającą się tu prawidłowość i stwierdzić, że warunkiem aktualności problematyki podejmowanej w ramach neofilozofii jest jej nieortodoksyjność. Dopiero z tej perspektywy można sensownie przystąpić do

${ }^{1}$ É. Gilson, Jedność doświadczenia filozoficznego, przeł. Z. Wrzeszcz, Warszawa 2001, s. 10.

${ }^{2}$ H. Schnädelbach, Nasz nowy neokantyzm, przeł. A. J. Noras, „Folia Philosophica”, red. P. Łaciak, t. 24. Katowice 2006, s. 16. 
analizy rozumienia idealizmu, które to pojęcie wydaje się kluczowe dla zrozumienia pojawiających się tu odmienności.

Warto jednak odwołać się do rozumienia historii filozofii mającego swe źródło w filozofii Kanta. Wolfgang Röd odwołuje się do pojęcia „filozofująca historia filozofii" i pisze:

Filozofująca historia filozofii pozostaje w opozycji do czystej historii idei, która - także wtedy, kiedy prezentuje tak interesujące wyniki - nie jest historią filozofii w ścisłym sensie i przede wszystkim dlatego nie może zastąpić tamtej, gdyż idee niezależne od związku z określoną filozofią nie posiadają żadnego znaczenia ${ }^{3}$.

Taki sens w studiowaniu dziejów filozofii znajduje również Hermann Lübbe, który historię filozofii postrzega jako filozofię, co nie zmienia faktu, że widzi tu pewne ograniczenia i wskazuje dwa jako najważniejsze. Po pierwsze przekonanie, że filozofia ustępuje miejsca historii filozofii, a wówczas „wcale nie istnieje owa problematyczna identyczność filozofii i historii filozofii”" Po drugie, chodzi o uniknięcie sytuacji, w której „zwrot filozofii do jej przeszłości można by interpretować jako zwrot do prawdziwej filozofii”s. Niewątpliwie te dwa uzupełniające się argumenty wymagają szczególnej troski w próbie określenia właściwej relacji pomiędzy filozofią a jej historią. Relacja ta nie jest przedmiotem poniższych badań, niemniej jednak warto o niej pamiętać, kiedy chce się zrozumieć zmiany zachodzące $\mathrm{w}$ ujęciu problemu poznania, który staje się problemem ugruntowania filozofii. Najbardziej lapidarnie ujmuje to Werner Flach w księdze jubileuszowej dedykowanej swemu nauczycielowi, Hansowi Wagnerowi, kiedy analizując opus vitae swego mistrza, podkreśla znaczenie pracy i pisze:

Także ona koncentruje się na temacie obiektywności poznania. I praca ta zawiera ponadto najbardziej znaną propozycję, którą od krytycznego stanowiska Kanta (w Krytyce czystego rozumu), że pytanie o obiektywność poznania jest

${ }^{3}$ W. Röd, Der Weg der Philosophie von den Anfängen bis ins 20. Jahrhundert, Bd. 1: Altertum, Mittelalter, Renaissance, München 1994, s. 16.

${ }^{4} \mathrm{H}$. Lübbe, Philosophiegeschichte als Philosophie. Zu Kants Philosophiegeschichtsphilosophie, [w:] Einsichten. Gerhard Krüger zum 60. Geburtstag, hrsg. von K. Oehler u. R. Schaeffler, Frankfurt am Main 1962, s. 205.

5 Tamże, s. 206. 
pytaniem o ugruntowanie ważności poznania, tylko nieliczni postępującą tematykę obiektywności poznania posuwają dalej'.

Pojawiło się w doktrynie Kanta pojęcie „filozofująca historia filozofii”, na co zwracają uwagę zarówno Wolfgang Röd, jak i Hermann Lübbe. W Löse Blätter zu den Fortschritten der Metaphysik znajduje się akapit tak właśnie zatytułowany (Von einer philosophirenden Geschichte der Philosophie) ${ }^{7}$. Istnieje także problem redakcji, gdyż to nie sam Kant przygotowywał tekst do druku, ale uczynił to Friedrich Theodor Rink, a Lübbe - powołując się na Gerharda Lehmanna - twierdzi, że wykorzystał on istniejący materiał „jako tako"8. Najważniejsza kwestia, jaka znajduje się we wspomnianym fragmencie brzmi następująco: „Czy historia filozofii sama może być częścią filozofii, czy też musi być historią uczoności w ogóle" mysł Kanta w następujący sposób: „Jego pytanie jest dokładnie takie, kiedy i przy spełnieniu jakich warunków przedstawienie historii filozofii jest samo filozofią"10.

II.

Hermann Cohen, przystępując do analizy doświadczenia, podejmuje polemikę ze stanowiskiem Friedricha Alberta Langego, swojego poprzednika na katedrze filozofii w Marburgu. Lange, opisując doświadczenie, wskazuje na rzekome istnienie tautologii, którą opisuje następująco: „Jeśli akcentuje się zbyt mocno jedynie transcendentalne stanowisko, to dochodzi się, jak już wspomniano do tautologii, że doświadczenie należy wyjaśnić w ogóle na podstawie warunków możliwego doświadczenia" ${ }^{11}$. Cohen podkreśla jednak,

6 W. Flach, Die Objektivität der Erkenntnis, [w:] Die Aktualität der Transzendentalphilosophie. Hans Wagner zum 60. Geburtstag, hrsg. von G. Schmidt u. G. Wolandt, Bonn 1977, s. 7.

7 I. Kant, Löse Blätter zu den Fortschritten der Metaphysik, [w:] tenże, Gesammelte Schriften. Akademie-Ausgabe, Bd. XX: Dritte Abteilung: Handschriftlicher Nachlaß. Siebenter Band, hrsg. von G. Lehmann, Berlin 1942, s. 333-351 (dalej cytowane jako AA XX).

${ }^{8}$ Zob. H. Lübbe, Philosophiegeschichte als Philosophie... s. 211.

${ }^{9}$ AA XX, 343.

${ }^{10}$ H. Lübbe, Philosophiegeschichte als Philosophie..., s. 211.

${ }^{11}$ „Treibt man die Betonung des bloss transscendentalen Standpunktes zu weit, so kommt man, wie bereits angedeutet auf die Tautologie, dass die Erfahrung zu erklären ist aus den Bedingungen überhaupt möglicher Erfahrung”. F. A. Lange, Geschichte des Materialismus und Kritik seiner Bedeutung in der Gegenwart, 2. Buch: Geschichte des Materialismus seit Kant, 2. verbess. u. verm. Auflage, Iserlohn 1875, s. 131. 
że stan faktyczny przedstawia się zupełnie odwrotnie i stwierdza: „w ogóle możliwe doświadczenie zostaje określone na podstawie warunków faktycznego doświadczenia. A to z pewnością nie jest żadna tautologia, jak wyraźnie poświadcza to dogmatyczna metafizyka" ${ }^{12}$. Cohen podkreśla, że również u Langego dokonuje się zwrot w kierunku tego, co metafizyczne, ponieważ autor Geschichte des Materialismus... stwierdza:

Skoro dedukcja transcendentalna zamiast tej tautologii winna wykazywać syntetyczny rezultat, to kategorie koniecznie muszą jeszcze być czymś, oprócz tego, że są one warunkami doświadczenia. Tego należy poszukiwać w doktrynie Kanta w ich określeniu „pojęcia pierwotne czystego rozumu”, podczas gdy my wysunęliśmy w tym miejscu „organizację"13.

Cohen pojęcie organizacji wiąże z neokantyzmem fizjologicznym, do którego reprezentantów zalicza się Langego i Hermanna von Helmholtza, i podkreśla, że skoro kategorie mają być a priori, to przecież nie mogą pochodzić ze świata rzeczy. Cohen pisze: „Zasady uzyskują swoje "źródła« w formach naszego myślenia, w funkcjach sądu; warunki doświadczenia stają się jego formalnymi warunkami” ${ }^{14} \mathrm{i}$ argument ten nazywa „argumentem metafizycznym".

Cohen kontynuuje: „W ten sposób wyłania się stosunek zasady do kategorii. Jeśli syntetyczna zasada ma dojść do transcendentalnej ważności, to w pierwszym rzędzie źródło kategorii musi być a priori” ${ }^{15}$. Zarazem jednak podkreśla autor, że ujawnia się tu dwuznaczność w samym rozumieniu aprioryczności, a dodatkowo - co postrzega jako słabość - nie wymazano „posmaku czasowości”'16. W dalszym toku rozumowania Cohen pisze:

Nie najprostsze i z tego powodu niemal aprioryczne elementy naszego myślenia-kt o mógłby j e zag wara n to wa ć - ale najbardziej dojrzałe

\footnotetext{
${ }^{12} \mathrm{H}$. Cohen, Kants Begründung der Ethik nebst ihren Anwendungen auf Recht, Religion und Geschichte, 2. verbess. u. erweit. Aufl., Berlin 1910, s. 33 (dalej cytowane jako KBE B).

${ }^{13}$ F. A. Lange, Geschichte des Materialismus und Kritik seiner Bedeutung in der Gegenwart, 2. Buch..., s. 131.

${ }^{14} \mathrm{KBE} \mathrm{B}, 35$.

${ }^{15} \mathrm{KBE} \mathrm{B}, 35$.

${ }^{16} \mathrm{KBE} \mathrm{B}, 35$.
} 
i historycznie najbardziej zagwarantowane zasady poznania zawierają pewność doświadczenia, stanowią rękojmię realności ${ }^{17}$.

Problem aprioryczności okazuje się zatem kluczowy dla zrozumienia doświadczenia, i to również w ujęciu Kanta, a Cohen kontynuuje swoją kwestię:

Warunki faktycznego doświadczenia, którymi są syntetyczne zasady, określają możliwość doświadczenia; a możliwość doświadczenia legitymizuje możliwość przedmiotów doświadczenia. Innymi, współczesnymi słowy: zasada, p r a w o jest wyrażeniem realności; prawo jest rzeczą samą w sobie ${ }^{18}$.

Problem, z jakim ma do czynienia ktoś, kto próbuje zrozumieć sam proces ugruntowania filozofii, polega na tym, że proces ten podlega u Cohena nieustannej ewolucji. Trzeba bowiem w pierwszym rzędzie zrozumieć doświadczenie, a tymczasem również ono podlega ewolucji. Cohen początkowo sprowadza problem do zrozumienia Kanta wbrew interpretacjom jego filozofii w czasach Cohenowi współczesnych, a problem widzi między innymi przez pryzmat sporu toczonego przez Trendelenburga i Fischera ${ }^{19}$. Zrozumieć doświadczenie natomiast, to dla Cohena zrozumieć dwie kwestie: kwestię aprioryczności i kwestię metody. Od pierwszej kwestii rozpoczyna analizę filozofii Kanta, kiedy w pierwszym zdaniu opublikowanej w roku 1871 książki poświęconej Kantowi pisze: „W prezentowanej książce podjąłem problem ponownego ugruntowania Kantowskiej nauki o aprioryczności”20. Druga kwestia pojawia się sześć lat później, kiedy pisze:

Dla mnie jednak filozofia Kantowska nie oznacza nic innego, aniżeli filozofię jako naukę. Nauka zaś musi być wprawdzie dogmatyką; jednakże nie jest dogmatem, i nie pozostaje czytaniem dokumentów. Nauka jest ideałem systemu na podstawie ciągłej metodycznej pracy ${ }^{21}$.

17 „Nicht die einfachsten und deshalb etwa apriorischen Elemente unseres Denkens - wer möchte sie verbürgen - sondern die reifsten und geschichtlich verbürgesten Grundsätze der Erkenntnis enthalten die Gewissheit der Erfahrung, bilden die Gewähr der Realität”. KBE B, $35-36$.

${ }^{18} \mathrm{KBE} \mathrm{B}, 36$.

${ }_{19}$ Zob. A. J. Noras, Debata Trendelenburg - Fischer. Problem obiektywności Kantowskich form zmysłowości, „Przegląd Filozoficzny - Nowa Seria” 2013, R. 22, nr 1, s. 267-297.

${ }^{20}$ H. Cohen, Kants Theorie der Erfahrung, Berlin 1871, s. III (dalej cytowane jako KTE A).

${ }^{21}$ H. Cohen, Kants Begründung der Ethik, Berlin 1877, s. III (dalej cytowane jako KBE A). 
Mając to na względzie, Geert Edel mówi o przeformułowaniu fundamentalnego założenia teorii doświadczenia, które wiąże z metodą transcendentalną 22 .

\section{III.}

Z przedstawionej pokrótce charakterystyki wynika fundamentalna kwestia odmienności rozumienia doświadczenia przez Cohena względem jego wielkich poprzedników. Wprawdzie Cohen punktem wyjścia swoich rozważań czyni stanowisko Kantowskie, ale kwestia zależności nie jest jednoznaczna. Na początku książki poświęconej rozumieniu doświadczenia jej autor stwierdza: „Kant odkrył nowe pojęcie doświadczenia. Krytyka czystego rozumu jest krytyką doświadczenia"23. Zarazem jednak pojawia się kwestia rozumienia doświadczenia, odmiennie pojętego u Kanta i Cohena. Co więcej - również sam Cohen ujawnia tu ewolucję swoich poglądów, kiedy charakteryzując odmienność idealizmu transcendentalnego od "zwykłego" idealizmu, inaczej formułuje myśl w wydaniu pierwszym, a inaczej w wydaniu drugim i trzecim.

I. Inaczej idealista transcendentalny. Wychodzi on od możliwości doświadczenia, od poznania. Jego pierwsze słowa brzmią: to, od czego musi się zaczynać wszelkie doświadczenie, wcale nie musi z niego wypływać. W ten sposób jego pierwszym krokiem jest abstrahowanie od materii doświadczenia. Dla niego nie stanowi ona początku wszelkiego myślenia ${ }^{24}$.

II. Inaczej idealista transcendentalny. Wychodzi on od doświadczenia naukowego. Jego pierwsze słowa brzmią: to, od czego musi się zaczynać wszelkie doświadczenie, wcale nie musi z niego wypływać. W ten sposób jego pierwszym krokiem jest abstrahowanie od materii doświadczenia. Dla niego nie stanowi ona początku wszelkiego myślenia ${ }^{25}$.

III. Inaczej idealista transcendentalny. Wychodzi on od doświadczenia naukowego. Jego pierwsze słowa brzmią: to, od czego musi się zaczynać wszelkie do-

${ }^{22}$ Zob. G. Edel, Von der Vernunftkritik zur Erkenntnislogik. Die Entwicklung der theoretischen Philosophie Hermann Cohens, Freiburg-München 1998, s. 100-201.

${ }^{23}$ KTE A, 3.

${ }^{24}$ KTE A, 243.

${ }^{25}$ H. Cohen, Kants Theorie der Erfahrung, 2. neubearb. Aufl., Berlin 1885, s. 605 (dalej cytowane jako KTE B). 
świadczenie, wcale nie musi z niego wypływać. W ten sposób jego pierwszym krokiem jest abstrahowanie od materii doświadczenia. Dla niego nie stanowi ona początku wszelkiego myślenia ${ }^{26}$.

W wydaniu pierwszym punktem wyjścia idealizmu transcendentalnego czyni Cohen „możliwość doświadczenia”, natomiast w wydaniu drugim „doświadczenie naukowe”. Zmiana stanowiska uzasadniona jest analizami zaprezentowanymi w czasie, jaki upłynął od opublikowania pierwszego wydania Kants Theorie der Erfahrung, a w którym opublikował dwie ważne książki, podejmujące problem doświadczenia. Najpierw pojawia się zagadnienie nauki w książce Kants Begründung der Ethik, a Cohen notuje: „W przeciwieństwie do dogmatycznego, materialnego realizmu mamy pewność realności uzależnioną od warunków, które umożliwia faktyczne naukowe doświadczenie"27. Problem zostaje ujęty jeszcze wyraźniej w kolejnej książce, kiedy Cohen zaczyna posługiwać się terminami „krytyka poznania” oraz „krytycznopoznawczy idealizm”. Pisze wówczas:

Idealizm w ogóle rozkłada rzeczy na zjawiska i idee. Krytyka poznania natomiast dzieli naukę na założenia i podstawy, które zostały przyjęte $\mathrm{w}$ ich prawach i dla nich samych. Teoriopoznawczo-krytyczny idealizm ma więc za swoje obiekty nie tylko rzeczy i procesy, także nie zgoła rzeczy i procesy świadomości, lecz fakty naukowe ${ }^{28}$.

IV.

Problem ugruntowania filozofii jest problemem rozumienia doświadczenia, które w koncepcji Cohena staje się doświadczeniem naukowym. Motyw ten staje się przewodnim motywem filozofii twórcy szkoły marburskiej, a widać to wyraźnie w książce Das Princip der Infinitesimal-Methode und seine Geschichte, kiedy pisze:

${ }^{26}$ H. Cohen, Kants Theorie der Erfahrung, 3. Aufl., Berlin 1918, s. 769 (dalej cytowane jako KTE C). Wydanie polskie: tenże, Kantowska teoria doświadczenia, przeł. A. J. Noras, Kęty 2012, s. 546 (dalej cytowane jako KTD).

27 „Entgegen einem dogmatischen, materialen Realismus haben wir die Gewissheit der Realität abhängig gemacht von den Bedingungen, welche die gegebene wissenschaftliche Erfahrung möglich machen". KBE A, 113.

${ }^{28}$ H. Cohen, Das Princip der Infinitesimal-Methode und seine Geschichte. Ein Kapitel zur Grundlegung der Erkenntnisskritik, Berlin 1883, s. 6 (\$9) (dalej cytowane jako PIM). 
Zatem to, co transcendentalne odnosi się do możliwości poznania, któremu przysługuje wartość apriorycznej bądź naukowej ważności. Krytyka poznania jest więc równoznaczna z logiką transcendentalną; ponieważ jej zadaniem jest odkrycie syntetycznych zasad albo tych podstaw poznawania, na których wznosi się nauka i od ważności których ona zależy. Założenie takich podstaw nie jest bynajmniej dogmatyczne; lecz odwrotnie, podejrzenie dogmatyzmu, o ile odnosi się go do tego przyjęcia, stanowi symptom dogmatyzmu. Supozycje i założenia muszą leżeć u podstaw nauki; ponieważ bez ukrytego bazowania nie może się wznosić żaden system nauki; wszelki rozwój twierdzeń zakłada zasady $^{29}$.

Logika transcendentalna wyznacza zatem, zdaniem Cohena, kierunek badań i staje się głównym ich przedmiotem. Wiąże się to z zakwestionowaniem wartości estetyki transcendentalnej. Idea logiki filozofii, stanowiącej próbę ugruntowania filozofii, jest wspólna reprezentantom neokantyzmu badeńskiego i marburskiego. Filozofem, który szczególnie się tu zasłużył jest Emil Lask ${ }^{30}$, mówiący wprost o logice filozofii, utożsamiając ją z problematyką ugruntowania filozofii. Konrad Hobe pisze o tym w następujący sposób:

$\mathrm{W}$ „logice filozofii” Lask odwraca się, jak mówi, prawie całkowicie od teorii wiedzy, a tym samym od przeciwieństwa między naukami przyrodniczymi a naukami o kulturze, i zajmuje się tym, co leży u podstaw obydwu, a mianowicie teorią poznania ${ }^{31}$.

\footnotetext{
29 „Denn das Transzendentale bezieht sich auf die Möglichkeit einer Erkenntniss, welcher der Werth apriorischer oder wissenschaftlicher Geltung zukommt. Die Erkenntnisskritik ist somit gleichbedeutend mit der transscendentalen Logik; denn ihre Aufgabe ist die Entdeckung der synthetischen Grundsätze oder derjenigen Grundlagen des Erkennens, auf welchen die Wissenschaft sich aufbaut, und von deren Geltung sie abhängt. Die Voraussetzung solcher Grundlagen ist keineswegs dogmatisch; sondern umgekehrt ist der Verdacht des Dogmatismus, sofern derselbe auf jene Annahme sich bezieht, ein Symptom des Dogmatismus. Annahmen und Voraussetzungen müssen der Wissenschaft zu Grunde liegen; denn ohne latente Basirung kann kein Lehrgebäude aufgerichtet werden; alle Entwickelung von Sätzen setzt Grundsätze voraus". PIM, 7 (\$9).

${ }^{30}$ Zob. A. J. Noras, Emil Lask. W stulecie śmierci, „Folia Philosophica”, red. P. Łaciak, t. 33, Katowice 2015, s. 31-49.

${ }^{31}$ K. Hobe, Emil Lask. Eine Untersuchung seines Denkens, Heidelberg 1968, s. 53.
} 
Wolfgang Marx podkreśla oprócz tego, że logika przestaje być kanonem i staje się organonem filozofii i teorii poznania ${ }^{32}$. Natorp stwierdza: „Logika, jako teoria poznania, chce wyjaśnić ich prawowity status, dzięki któremu poznanie stanowi wewnętrzną jedność" ${ }^{33}$. Werner Flach wskazuje ponadto na istnienie „najbardziej znaczącej interpretacji Kanta w ramach badeńskiej szkoły neokantyzmu, a może nawet w ramach neokantyzmu w ogóle"34, którą stanowi książka Brunona Baucha opublikowana w roku $1917^{35}$.

Niewątpliwie istotnym elementem wyznaczającym kierunek badań jest sposób, w jaki zinterpretowana zostaje filozofia Kanta. Uchwycenie tego stanu rzeczy wymagałoby zaś powrotu do koncepcji myśliciela z Królewca. Przystępując do analizy metody w filozofii neokantowskiej, Werner Flach pisze:

Niniejszym jest rozstrzygnięte: podejmowane rozważania biorą za swój pierwotny punkt orientacyjny filozofię Kanta. Wychodzą one od tego, że w filozofii Kanta znajduje się oryginalne sformułowanie tego, co zakładając historycznie może zostać nazwane metodą krytycystyczną ${ }^{36}$.

Powody są co najmniej dwa. Pierwszy powód wskazuje Flach, podkreślając, że jego decyzja jest ugruntowana historycznie, a mianowicie końcowym fragmentem Krytyki czystego rozumu, gdzie czytamy: „Jedynie droga krytyczna stoi jeszcze otworem" ${ }^{37}$. W tej sytuacji Flach podkreśla krytyczny charakter filozofii Kanta i stwierdza:

Droga, która jedynie stoi jeszcze otworem do legitymizacji wiedzy, droga odpowiednia dla rzeczy i pod tym względem nieodzowna pod względem systematy-

\footnotetext{
${ }^{32}$ Zob. W. Marx, Die philosophische Entwicklung Paul Natorps im Hinblick auf das System Hermann Cohens. In: Materialien zur Neukantianismus-Diskussion, hrsg. von H.-L. Ollig, Darmstadt 1987, s. 69.

${ }^{33}$ P. Natorp, O obiektywnym bądź subiektywnym ugruntowaniu poznania, przeł. W. Marzęda, [w:] Neokantyzm badeński i marburski. Antologia tekstów, red. A. J. Noras, T. Kubalica, Katowice 2011, s. 219.

${ }^{34}$ W. Flach, Das Problem der transzendentalen Deduktion: seine Exposition in der Kritik der reinen Vernunft und seine Wiederaufnahme im Neukantianismus der südwestdeutschen Schule. In: Materialien zur Neukantianismus-Diskussion, hrsg. von H.-L. Ollig, Darmstadt 1987, s. 151.

${ }^{35}$ B. Bauch, Immanuel Kant, Berlin-Leipzig 1917.

${ }^{36}$ W. Flach, Kritizistische oder dialektische Methode? Analyse und Bewertung, [w:] Der Neukantianismus und das Erbe des deutschen Idealismus: die philosophische Methode, hrsg. von D. Pätzold u. Ch. Krijnen, Würzburg 2002, s. 9.

${ }^{37}$ KCR B, 884.
} 
ki legitymizacji wiedzy z ważnością wyposażona droga, systematycznie ważna metoda jest metodą krytyczną bądź też właśnie krytycystyczną ${ }^{38}$.

Drugi powód - ściśle z pierwszym związany - dotyczy rozwoju filozofii transcendentalnej po Kancie i nierozerwalnie wiąże się z próbą odpowiedzi na pytanie: czy filozofia ta rzeczywiście idzie śladem Kanta, czy też postępowanie tropem myśliciela $\mathrm{z}$ Królewca wiąże się z interpretacją jego filozofii.

Hermann Cohen, analizując dedukcję transcendentalną, którą czyni ośrodkiem swej filozofii i uznaje za centrum filozofii Kanta, wskazuje na odmienność jej rozumienia przez Kanta i Fichtego. U podstaw tego rozróżnienia leży przekonanie, że rozwój filozofii po Kancie nie jest jednolity i dlatego nie można Fichtego uważać za kontynuatora myśli Kanta:

U Fichtego - pisze Cohen - dedukcja transcendentalna polega na wywodzie $\mathrm{z}$ samowiedzy. Dowodem pojęcia jako warunku samowiedzy jest jego dedukcja. U Kanta natomiast dedukcja jest wywodem z warunków doświadczenia; a do nich, obok jedności samowiedzy należy różnorodność naoczności ${ }^{39}$.

Neokantysta Cohen ma więc świadomość odstępstwa Fichtego od Kanta, a pośrednio idealistów niemieckich od Kanta. W konsekwencji buduje się tu warstwowa zależność nurtów występujących po Kancie i do niego nawiązujących. Jest ona tym bardziej złożona, że w neokantyzmie ujawnia się ponadto problem obecności myśli Hegla.

\section{V.}

Analizując konieczność zasady przyczynowości u Kanta, Cohen dochodzi do następującego wniosku: „System Kanta nie upadnie wraz z odrzuceniem tego wywodu. Nie opiera się on na metafizycznej, ale na transcendentalnej dedukcji kategorii" ${ }^{\prime \prime}$. Natomiast w wydaniu drugim zdanie to uzupełnione zostaje w następujący sposób: „Myśl tę możemy teraz wyrazić również tak: System doświadczenia polega na dedukcji zasad" ${ }^{41}$. Pojawia się tu zresztą problem najwyższej zasady syntetycznych sądów a priori, która koniec końców stanowi ostateczną podstawę ważności naszej wiedzy oraz podstawę deduk-

\footnotetext{
${ }^{38}$ W. Flach, Kritizistische oder dialektische Methode?..., s. 9.

${ }^{39} \mathrm{KBE}$ A, 45.

${ }^{40}$ KTE A, 207 (KTD, 379).

${ }^{41}$ KTE B, 409 (KTD, 379).
} 
$\mathrm{cji}^{42}$. Edel podaje tu cztery warunki określające rozumienie wiedzy przez Cohena, a mianowicie ${ }^{43}$ :

a) możliwość doświadczenia zostaje określona jako „esencja” (Springpunkt), tzn. jako ostateczna podstawa dedukcji i podstawa ważności transcendentalnej teorii poznania;

b) „najwyższa zasada” formułuje najwyższe pryncypium (prawo myślenia), na mocy którego poznania dedukowane z „esencji” (Springpunkt) charakteryzuje obiektywna realność;

c) należy zatem ściśle odróżnić „esencję” (Springpunkt) i najwyższe pryncypium (prawo myślenia), chociaż są one nierozerwalnie ze sobą powiązane;

d) sama „najwyższa zasada” nie stwierdza już obiektywnej realności bądź tylko ją, o ile formułuje ona pryncypium ważności jednostkowych zasad (jako warunków przedmiotów), a więc musi zostać pryncypium, które dla każdej jednostkowej zasady jakby na nowo musiało zostać przewidziane i wymagane.

\section{VI.}

Cohen podejmuje problem dedukcji transcendentalnej, jako fundamentalny dla rozumienia doświadczenia $\mathrm{w}$ świetle jego prawomocności. W pierwszym wydaniu Kants Theorie der Erfahrung (1871) podkreśla rozumienie jej w duchu Kanta i pisze:

Zadaniem dedukcji transcendentalnej jest udowodnienie owej wzajemnej zgodności źródeł poznania przynajmniej co do jej możliwości: udowodnienie sposobu „w jaki pojęcia mogą a priori odnosić się do przedmiotów”, to znaczy dokładniej, odnosić się do „danych” dzięki zmysłowości przedmiotów, w ten sposób, że to, co dane, określając to, co pomyślane, wypełnia pojęcie przedmiotu $^{44}$.

W świetle tego „Dedukcja jest »uzasadnieniem« istniejących w filozofii »zasad»"45.

\footnotetext{
${ }^{42}$ Zob. G. Edel, Von der Vernunftkritik zur Erkenntnislogik..., s. 138.

${ }^{43}$ Zob. tamże, s. 139.

${ }^{44}$ KTE A, 123 (KTD, 284). Fragment tekstu Kanta to KCR B, 117.

${ }^{45}$ KTE A, 125 (KTD, 286).
} 
W wydaniu drugim Kants Theorie der Erfahrung (1885) Cohen podkreśla procesualny charakter tworzenia się kategorii i stwierdza, że „[...] samą formę Kant pomyślał aktywnie i werbalnie, a zatem jest rozumiana jako proces i dlatego czas i przestrzeń, tak też kategorie powstają w syntezie i wraz $\mathrm{z}$ nią" ${ }^{46}$. Jest to ściśle związane z przekonaniem Cohena, że drugie wydanie Krytyki czystego rozumu Kanta charakteryzuje antypsychologizm, którego brak w wydaniu pierwszym. „Kant - pisze Cohen - w transcendentalnej dedukcji drugiego wydania odrzucił pogląd o pojęciach intelektu jako »[subiektywnymi] zaszczepionymi nam wraz z naszym istnieniem uzdolnieniami do myślenia « jako »system performacyjny czystego rozumu «"47. Innymi słowy, Kant odrzuca tu możliwość, do której nawiązuje później Johann Friedrich Herbart w swojej psychologii. Oczywiście problem jest bardziej złożony, ponieważ w tym samym stopniu dotyczy tych wszystkich, którzy odwołują się do szeroko rozumianej psychologii i jej roli w procesie ugruntowania filozofii. Oprócz Herbarta trzeba więc jeszcze wskazać Jakoba Friedricha Friesa i Jürgena Bona Meyera - by wspomnieć tych najważniejszych.

Cohen podkreśla: „Celem wszelkich badań transcendentalnych jest więc wyjaśnienie możliwości syntetycznych sądów a priori na podstawie aprioryczności syntetycznych zasad" ${ }^{\prime 8}$. Ale już w rozdziale ósmym, kiedy analizuje Cohen znaczenie transcendentalnej dedukcji kategorii odwołuje się do słów Kanta, w których myśliciel z Królewca tłumaczy sens dedukcji transcendentalnej. Cohen wskazuje na drugie wydanie Krytyki czystego rozumu (1787), gdzie czytamy:

Wyjaśnienie sposobu, w jaki pojęcia mogą a priori odnosić się do przedmiotów, nazywam ich transcendentalną dedukcją i odróżniam ją od dedukcji empirycznej, która pokazuje sposób, w jaki pojęciu uzyskujemy z doświadczenia i z zastanowienia się nad nim, a przeto dotyczy nie jego prawności, lecz faktu, z którego pochodzi jego posiadanie ${ }^{49}$.

Nie dodaje jednak, że zdanie to występuje w takiej samej postaci już w wydaniu pierwszym ${ }^{50}$. Co więcej, Cohen tłumaczy sens logiki transcendentalnej w odróżnieniu od stanowiska Meyera i pisze: „Jako równie fundamentalny

\footnotetext{
${ }^{46} \mathrm{KTE} \mathrm{B}, 246$ (KTD, 245).

${ }^{47}$ KTE B, 252 (KTD, 250). Fragment tekstu Kanta to KCR B, 167.

${ }^{48}$ KTE B, 407 (KTD, 378).

${ }^{49} \mathrm{KCR} \mathrm{B}, 117$.

${ }^{50}$ Zob. KCR A, 85.
} 
błąd należy określić pogląd, że »logika transcendentalna ma być wydzielona przez Kanta z ogólnej czystej logiki«, jako metafizyczna praca wstępna. Raczej logika transcendentalna zakłada logikę ogólną. Dopiero w niej, odnośnie do pewnych pytań wyjaśniających, psychologię można uważać za założenie. Skoro zaś obok psychologii ma istnieć krytyka poznania, to dedukcję transcendentalną należy rozważać jako badanie istniejące w krytyce poznania i tylko ze względu na jej przygotowawcze początki kształcenia, a nie jako badanie stykające się z psychologią ${ }^{51}$. Innymi słowy, logika transcendentalna zostaje wskazana jako posiadająca fundamentalne znaczenie dla filozofii krytycznej. Cohen wskazuje na Friesa i jego ujęcie „przesądu transcendentalnego”. Polegać ma on na tym, „Kant dedukcję »myli« $\mathrm{z}$ dowodem” ${ }^{2}$.

Cohen tłumaczy rozumienie dedukcji transcendentalnej w pierwszym wydaniu Krytyki czystego rozumu i pisze:

Struktura tego zakresu tworzy treść dedukcji transcendentalnej, istniejącej $\mathrm{w}$ dowodzie: że procesy, jak psychiczne posługiwanie się poznaniem, sprowadzone z powrotem do podstawowej postaci je d n oś c i ś wi a d o m oś ci, rozwijają szereg zjawisk jako całość doświadczenia ${ }^{53}$.

Z perspektywy późniejszej ewolucji filozofii Cohena warte uwagi jest to, że pojawia się tu pojęcie jedności świadomości. Przy okazji tłumaczy Cohen odmienność dedukcji transcendentalnej od dedukcji empirycznej. „Tamta pisze autor Kants Theorie der Erfahrung - zakłada pryncypium możliwości doświadczenia; ta zaś podaje "okolicznościowe przyczyny« jego powstania" ${ }^{54}$. Wydanie drugie Krytyki czystego rozumu przynosi rozwinięcie problemu dedukcji transcendentalnej, które znajduje wyraz w pojęciu transcendentalnej apercepcji. A Cohen podsumowuje swoje rozważania poświęcone temu zagadnieniu w następujący sposób: „Zadania dedukcji możemy sobie uświadomić $\mathrm{w}$ czterech ważnych porównaniach. $1^{\circ}$ Przedmiot znajduje się $\mathrm{w}$ kategoriach. $2^{\circ}$ Kategoria jest jednością syntezy. $3^{\circ}$ Samowiedza staje się przedmiotem $\mathrm{w}$ kategorii. $4^{\circ}$ Samowiedza istnieje $\mathrm{w}$ jedności syntezy tego, co różnorodne" ${ }^{55}$.

${ }^{51}$ KTE B, 296 (KTD, 284). Fragment z oryginału to: J. B. Meyer, Kants Psychologie, Berlin 1870, s. 175.

${ }^{52}$ KTE B, 297 (KTD, 286).

${ }^{53}$ KTE B, 300 (KTD, 289).

${ }^{54}$ KTE B, 300 (KTD, 289). Fragment tekstu Kanta to KCR B, 118.

${ }^{55} \mathrm{KTE} \mathrm{B}, 321$ (KTD, 306). 
VII.

Transcendentalna apercepcja, jak zauważa Herbert James Paton (18871969), stanowi centrum filozofii Kanta ${ }^{56}$. Oznacza ona, że przedmiot poznania jest syntetyczną jednością, a jedność przedmiotu jest konsekwencją jedności świadomości. Sam Kant ujmuje tę kwestię następująco:

Wszelka różnorodność danych naocznych zawiera więc w sobie konieczne odniesienie do owego „Myślę" występujące w tym samym podmiocie, w którym znajduje się ta różnorodność. Przedstawienie to jest jednak aktem samorzutności, tzn. nie można go uważać za należące do zmysłowości. Nazywam jest dla odróżnienia od empirycznej apercepcji apercepcją czystą lub też apercepcją pierwotną, ponieważ jest ono tą samowiedzą (Selbstbewusstsein), która wytwarzając przedstawienie „Myślę” - które musi móc towarzyszyć wszelkim innym przedstawieniom i we wszelkiej świadomości jest jedno i to samo - nie może już sama być wyprowadzona $\mathrm{z}$ żadnego innego przedstawienia. Jedność tej apercepcji nazywam też transcendentalną jednością samowiedzy, aby zaznaczyć możliwość pochodzenia z niej poznania a priori ${ }^{57}$.

Problem apercepcji ujawnia się również wówczas, kiedy chodzi o rozumienie systemu u Kanta. W pierwszym wydaniu Krytyki czystego rozumu Kant zauważa:

Możliwość doświadczenia jest więc tym, co wszystkim naszym poznaniom a priori nadaje przedmiotową ważność. Otóż doświadczenie polega na syntetycznej jedności zjawisk, to jest na dokonującej się wedle pojęć syntezie przedmiotu zjawisk w ogóle, bez której nie byłoby ono nawet poznaniem, lecz tylko pewnego rodzaju rapsodią złożoną ze spostrzeżeń, które w żadnym kontekście nie przystosowywałyby się do siebie wedle prawideł nieprzerwanie wewnętrznie powiązanej (możliwej) świadomości, a więc także nie nadawałyby się do transcendentalnej i koniecznej jedności apercepcji ${ }^{58}$.

\footnotetext{
56 „This is the point at which we really come to grips with the most central, the most important, and yet in some ways the most elusive, of all Kant's doctrines". H. J. Paton, Kant's Metaphysic of Experience. A Commentary on the First Half of the Kritik der reinen Vernunft, London 1936, vol. 1, p. 397.

${ }^{57}$ KCR B, 132.

${ }^{58}$ KCR A, 156 (AA IV, 109-110).
} 
Kant już w wydaniu pierwszym zwraca uwagę na konieczność istnienia warunku transcendentalnego, który znajdować się musi „u podstaw wszelkiej konieczności" ${ }^{59}$, i pisze:

Musi się więc dać znaleźć transcendentalne podłoże jedności świadomości w syntezie różnorodności wszelkich naszych danych naocznych, a więc także w syntezie pojęć przedmiotów w ogóle, a stąd także wszelkich przedmiotów doświadczenia. Bez tej podstawy byłoby niemożliwe pomyśleć jakiś przedmiot przynależący do naszych danych naocznych; nie jest on bowiem niczym więcej jak tym czymś, czego pojęcie wyraża konieczność syntezy. Ów zaś pierwotny i transcendentalny warunek nie jest niczym innym jak transcendentalną apercepcją ${ }^{60}$.

W wydaniu drugim Kant wyjaśnia problem w następujący sposób: „Świadomość samego siebie (apercepcja) jest prostym przedstawieniem [swego] Ja, i jeżeli by już przez to samo wszelka różnorodność w podmiocie była samoczynnie dana, to oglądanie wewnętrzne byłoby intelektualne"61. W nieco dalszym zaś miejscu: „Świadomość samego siebie jest więc jeszcze daleka od poznania samego siebie, bez względu na wszelkie kategorie, które tworzą myślenie jakiegokolwiek przedmiotu w ogóle przez powiązanie tego, co różnorodne w jednej apercepcji”' ${ }^{2}$.

Analizując filozofię Kanta już w pierwszym wydaniu Kants Theorie der Erfahrung, Cohen zwraca uwagę na źródłowość apercepcji, a mianowicie kiedy pojawia się pojęcie „ursprüngliche Apperception”63. Źródłowość, pierwotność oznacza więc dla Cohena warunki transcendentalnej apercepcji. Cohen odwołuje się do Kanta i pisze: „»Tę to czystą pierwotną, niezmienną świadomość « nazywam transcendentalną apercepcją" ${ }^{4}$. Kiedy następnie Cohen przystępuje do analiz transcendentalnej apercepcji w drugim wydaniu kantowskiej Krytyki czystego rozumu, wówczas wskazuje na to, że „Kant

\footnotetext{
${ }^{59}$ KCR A, 106.

${ }^{60} \mathrm{KCR}$ A, 106-107.

${ }^{61} \mathrm{KCR} \mathrm{B}, 68$.

${ }^{62}$ KCR B, 158.
}

${ }^{63}$ KTE A, 129 (KTD, 290). W tłumaczeniu Kants Theorie der Erfahrung na język polski posłużyłem się zwrotem „pierwotny” na oznaczenie niemieckiego „ursprünglich” ze względu na tłumaczenie Krytyki czystego rozumu przez Romana Ingardena. Natomiast w zgodzie z duchem filozofii Cohena „ursprünglich” to „źródłowy”.

${ }^{64}$ „»Dieses reine, ursprüngliche, unwandelbare Bewusstsein« ist die transscendentale Apperception". KTE A, 133 (KTD, 294). 
rozpoczyna mówieniem »o pierwotnie-syntetycznej jedności apercepcji«"65. Znowu trzeba podkreślić, że Kant mówi tu o „ursprünglich-synthetischen Einheit der Apperception" ${ }^{66}$, co w duchu Cohena można przetłumaczyć jako „źródłowo-syntetyczna jedność apercepcji”. Jest to ważne dlatego, że ostatecznie Cohen sprowadza problem ugruntowania filozofii i nauki do problemu źródła (Ursprung). Niezwykle trafnie charakteryzuje ten moment u Cohena Joseph Klein, który pisze: „Logika czystego poznania prezentuje wprost gigantycznie racjonalistyczną próbę, zabezpieczenia autonomii myślenia w zasadzie źródła absolutnej autonomii myślenia" ${ }^{\prime 7}$.

Kant nie jest specjalnie oryginalny w ujęciu apercepcji - rozumie ją w duchu Leibniza, jako samoświadomość. Rozważaniami poświęconymi zagadnieniu apercepcji rozpoczyna się Antropologia w ujęciu pragmatycznym ${ }^{68}$, książka napisana w roku 1798. Książka zaczyna się następującym zdaniem: „Człowiek dzięki temu, że może mieć przedstawienie swego ja, wyniesiony jest nieskończenie wysoko ponad wszystkie inne żyjące na ziemi istoty"69. Następnie Kant zwraca uwagę na to, że „apercepcja może być rozumiana jako świadomość w refleksji i świadomość we wrażliwości zmysłowej" ${ }^{\prime}$. Tutaj jednak w oryginale mówi Kant o ujmowaniu (Apprehension), ponieważ pisze: „so kann das Bewußtsein seiner selbst (apperceptio) in das der Reflexion und das der Apprehension eingetheilt werden"71. Pierwsza jest świadomością intelektualną, natomiast druga - zmysłem wewnętrznym, a Kant dodaje: „[...] pierwsza jest c z y s t ą apercepcją, druga - apercepcją empiryczną, przeto niesłusznie świadomość intelektualną określa się mianem z m y s ł u wewnętrznego"72. I wreszcie Kant zwraca uwagę na problem z rozumieniem ujmowania, pisząc:

${ }^{65}$ KTE A, 139 (KTD, 304). Fragment tekstu Kanta to KCR B, 131.

${ }^{66}$ AA III, 108.

${ }^{67}$ J. Klein, Die Grundlegung der Ethik in der Philosophie Hermann Cohens und Paul Natorpseine Kritik des Neukantianismus, Göttingen 1976, s. 25.

${ }^{68}$ I. Kant, Antropologia w ujęciu pragmatycznym, przeł. E. Drzazgowska, P. Sosnowska. Wstęp A. Bobko. Warszawa 2005, s. 9-11 (\$ 1), $20(\$ 4), 30-32(\$ 7)$.

${ }^{69}$ Tamże, s. 9.

${ }^{70}$ Tamże, s. 20.

${ }^{71}$ I. Kant, Anthropologie in pragmatischer Hinsicht, [w:] Gesammelte Schriften. Akademie-Ausgabe. Bd. VII: Erste Abteilung: Werke. Siebenter Band, Berlin 1917, s. 134 (dalej cytowane jako AA VII).

${ }^{72}$ I. Kant, Antropologia w ujęciu pragmatycznym..., s. 20. 
Że za pośrednictwem zmysłu wewnętrznego poznajemy siebie tylko tak, $\mathrm{j}$ a $\mathrm{k}$ $\mathrm{s}$ i ę $\mathrm{s}$ o b i e u ka z u je my, jest widoczne na tej podstawie, iż ujmowanie (apprehensio) jego wrażeń zakłada formalny warunek naoczności podmiotu, to znaczy czas, który nie jest pojęciem intelektu, a co za tym idzie, obowiązuje tylko jako subiektywny warunek sposobu, w jaki zgodnie z uposażeniem duszy ludzkiej dane są wrażenia wewnętrzne; ujmowanie nie pozwala nam więc poznać siebie jako obiektów samych w sobie ${ }^{73}$.

\section{VIII.}

Johann Gottlieb Fichte miał świadomość trudności z rozumieniem apercepcji i przeformułował Kantowskie pytanie, stawiając je w sposób ogólniejszy. Nie pyta o możliwość doświadczenia jak Kant, lecz o możliwość wiedzy, a w konsekwencji tworzy teorię wiedzy (Wissesnchaftslehre). W tej sytuacji do rangi problemu filozofii pokantowskiej urasta problem Fichtego, a nie problem Kanta. To jedynie tłumaczy zapędy wszystkich krytyków filozofii Kanta. Skoro uznali, że problem należy postawić, to jednocześnie odrzucić musieli krytycyzm Kanta i przyjąć stanowisko Fichtego. Wobec takiego stanu rzeczy sytuacja neokantystów jest szczególna, ponieważ nie mogą bronić filozofii Kanta w całej rozciągłości i dzieje się to kosztem ortodoksji. Jednocześnie muszą próbować ugruntować filozofię w inny sposób, niż uczynił to myśliciel z Królewca, a punktem odniesienia staje się właśnie Fichte. Zatem problematyczność ujawniającej się tu sytuacji polega na tym, że reprezentanci neokantyzmu są jednocześnie reprezentantami neofichteanizmu ${ }^{74}$.

Fichte swój zamysł dotyczący rozumienia doświadczenia tłumaczy następująco:

Otóż filozofia ma wskazać podstawę wszelkiego doświadczenia, a wobec tego przedmiot jej musi koniecznie leżeć poza wszelkim doświadczeniem. Teza ta obowiązuje w każdej filozofii i rzeczywiście obowiązywała powszechnie, póki nie pojawili się kantyści ze swymi faktami świadomości, a zatem doświadczenia wewnętrznego ${ }^{75}$.

\footnotetext{
73 Tamże, s. 32.

${ }^{74} \mathrm{Na}$ temat tego ostatniego pisałem w: A. J. Noras, O badaniach recepcji filozofii Kanta, „Studia z Historii Filozofii" 2014, 3(5), s. 115-128.

${ }^{75}$ J. G. Fichte, Pierwsze wprowadzenie do teorii wiedzy, przeł. J. Garewicz, [w:] J. G. Fichte, Teorie Wiedzy. Wybór pism, t. 1, przeł. M. J. Siemek, aneks przeł. J. Garewicz, Warszawa 1996, s. 473.
} 
W tych dwóch pochodzących z Pierwszego wprowadzenia do teorii wiedzy zdaniach zawarty jest program epistemologiczny całej filozofii pokantowskiej, nie tylko Fichtego, ale również neokantyzmu. Krytyka kantystów jest jednak nieuprawomocniona, gdyż również oni próbują zrozumieć doświadczenie, a zarzut ze strony Fichtego jest zasadny jedynie dlatego, że nie czynią tego w sposób dla niego możliwy do zaakceptowania. Zamysł Fichtego niezwykle trafnie tłumaczy Justyna Nowotniak, pisząc: „»Wyjaśnić« doświadczenie znaczy dla Fichtego w pierwszym rzędzie: wskazać jego podstawę i wywieść je, wyprowadzić z tej podstawy"76.

IX.

Zatem postępując $\mathrm{w}$ duchu neofichteanizmu, neokantyści - badeńscy i marburscy - będą poszukiwali podstawy, która umożliwia zbudowanie systemu wiedzy. Hermann Cohen odwołuje się tu do pojęcia hypothesis. Władysław Tatarkiewicz, polski marburczyk, wskazuje na fakt, że pojęcie to powiązane jest w myśli Cohena z filozofią Platona:

Idę̨ w takim znaczeniu nazywa Platon: v́ró $\theta \varepsilon \sigma \iota c$. Nie znaczy to: hypoteza, założenie, lecz przeciwnie: największa pewność. Polskie słowo $\mathrm{p}$ o d s t a w a jest najdokładniejszym tłumaczeniem greckiego »úró $\theta \varepsilon \sigma \iota \varsigma$; jest w nim ta sama aktywność i ma to samo ściśle znaczenie: podstawowy, czyli najpewniejszy ${ }^{77}$.

Już na początku swojej drogi filozoficznej odwołuje się Cohen do Platona, a wraz z tym odwołaniem pojawia się pojęcie hypothesis. W 1878 r. - w rok po opublikowaniu Kants Begründung der Ethik - Cohen wydaje książeczkę poświęconą Platonowi ${ }^{78}$, w której pisze: „S a m a id e a zostaj e pomyśla n a jak o hy p othe s i s"79. Teoria poznania Kanta zostaje zinterpretowana w duchu Platona, a konsekwencją jest krytyka poznania.

Geert Edel próbuje ostatecznie wyjaśnić sens stanowiska Cohena i pisze:

\footnotetext{
${ }^{76}$ J. Nowotniak, Samowiedza filozofa. Johanna Gottlieba Fichtego poszukiwanie jedności, Warszawa 1995, s. 13.

77 W. Tatarkiewicz, Spór o Platona, „Przegląd Filozoficzny” 1911, R. 14, z. 3, s. 351.

${ }^{78} \mathrm{H}$. Cohen, Platons Ideenlehre und die Mathematik, Marburg 1878. Tłumaczenie polskie: tenże, Teoria idei Platona a matematyka, tłum. A. J. Noras. „Idea - Studia nad strukturą i rozwojem pojęć filozoficznych", 2014, nr 26, s. 420-443 (Dalej cytowane jako TIP).

${ }^{79}$ TIP, 439.
} 
Transcendentalne ugruntowanie poznania, względnie nauki, które Cohen realizuje $\mathrm{w}$ logice poznania, dokonuje się $\mathrm{z}$ tego powodu nie na drodze zwrotnego powiązania poznania naukowego $\mathrm{z}$ podmiotem transcendentalnym, nie dzięki jego sprowadzeniu do źródłowych, tzn. hypothesis-ostatnich elementów, form albo fikcji świadomości poznającej; i tak samo jak dowód stosowalności, np. czystej matematyki zostaje sprowadzona do doświadczenia zewnętrznego. Lecz z obydwu względów, tzn. nie tylko tego, który odnosi się do regresu do podmiotu, lecz także tego, który dotyczy sięgania do świata rzeczy materialnych, pozostaje ściśle immanentne poznawczo i istnieje jedynie w rozwinięciu systemu sądów wzg. rodzajów sądów i pojęć podstawowych (kategorii), które jako „czyste” logiczne założenia i podstawy każdorazowo są wyróżnione $\mathrm{w}$ przyporządkowanym im obszarom poznania wzg. rodzajom nauki ${ }^{80}$.

$\mathrm{X}$.

Hermann Cohen ujawnia konsekwencję w procesie ugruntowania filozofii i nauki, który trwa de facto od opublikowania pierwszego wydania Kants Theorie der Erfahrung (1871) aż do Logik der reinen Erkenntnis (1902), a więc ponad trzydzieści lat. Proces ten koncentruje się na ugruntowaniu poznania, a ewolucyjny charakter ujawnia się ze względu na trudności piętrzące się przed Cohenem. Eggert Winter podkreśla, że „[...] temat Logik der reinen Erkenntnis stanowi problem odkrycia i ugruntowania tych warunków, które gwarantują obiektywną ważność doświadczenia"\$1. Problem wszakże polega na tym, że można i należy to uznać za motyw przewodni całej filozofii Cohe-

${ }^{80}$ „Die transzendentale Erkenntnis- bzw. Wissenschaftsbegründung, die Cohen in der Erkenntnislogik durchführt, vollzieht sich deshalb nicht auf dem Wege einer Rückbindung der wissenschaftlichen Erkenntnis an das transzendentale Subjekt, nicht durch ihre Rückführung auf ursprüngliche, d. h. hypothetisch-letzte Elemente, Formen oder Funktionen des erkennenden Bewusstseins; und sie wird ebensowenig als ein Nachweis der Anwendbarkeit z. B. der reinen Mathematik auf die Gegenstände der äußeren Erfahrung geführt. Sondern sie bleibt in beiden Hinsichten, d. h. sowohl was den Rückgang ins Subjekt als auch was den Ausgriff in die Welt der materiellen Dinge betrifft, strikt erkenntnisimmanent und besteht lediglich in der Entfaltung eines Systems von Urteilen bzw. Urteilsarten und Grundbegriffen (Kategorien), die als ,reine logische Voraussetzungen und Grundlagen der ihnen jeweils zugeordneten Erkenntnisgebiete bzw. Wissenschaftsarten ausgezeichnet werden”. G. Edel, Kantianismus oder Platonismus? Hypothesis als Grundbegriff der Philosophie Cohens, [w:] „Il Cannocchiale. Rivista di studi filosofici” 1991, Bd. 1-2: I filosofi della scuola di Marburgo, s. 64-65.

${ }^{81}$ E. Winter, Ethik und Rechtswissenschaft. Eine historisch-systematische Untersuchung zur Ethik-Konzeption des Marburger Neukantianismus im Werke Hermann Cohens, Berlin 1980, s. 202. 
na, i to nie tylko teoretycznej, co będzie jeszcze przedmiotem analiz. Cohen okazuje się tu idealistą - idealizm krytyczny to najbardziej właściwe określenie doktryny marburskiej - wyznającym zasadę, że „wszelkie nasze poznanie przedmiotu zależy od pryncypiów, na których opiera się ważność naszego poznania bytu" ${ }^{\prime 2}$. Pozostaje to $\mathrm{w}$ zgodzie $\mathrm{z}$ przeświadczeniem Wintera, że $\mathrm{w}$ koncepcji Cohena Ursprung $=$ principium $^{83}$, a więc poszukiwanie źródła ostatecznie nie jest niczym innym, jak poszukiwaniem zasad organizujących poznanie i gwarantujących jego obiektywną ważność. $Z$ tego powodu problematyka teoretyczno-ważnościowa stanowi najważniejszy element doktryny neokantystów i tych, którzy do neokantyzmu nawiązują.

\section{Bibliografia}

Bauch B., Immanuel Kant, Berlin-Leipzig 1917.

Cohen H., Das Princip der Infinitesimal-Methode und seine Geschichte. Ein Kapitel zur Grundlegung der Erkenntnisskritik, Berlin 1883.

Cohen H., Kants Begründung der Ethik nebst ihren Anwendungen auf Recht, Religion und Geschichte, 2. verbess. u. erweit. Aufl., Berlin 1910.

Cohen H., Kants Begründung der Ethik, Berlin 1877.

Cohen H., Kants Theorie der Erfahrung, Berlin 1871.

Cohen H., Kants Theorie der Erfahrung, 2. neubearb. Aufl., Berlin 1885.

Cohen H., Kants Theorie der Erfahrung, 3. Aufl., Berlin 1918.

Cohen H., Platons Ideenlehre und die Mathematik, Marburg 1878.

Cohen H., Teoria idei Platona a matematyka, przeł. A. J. Noras, „Idea - Studia nad strukturą i rozwojem pojęć filozoficznych" 2014, nr 26.

Edel G., Kantianismus oder Platonismus? Hypothesis als Grundbegriff der Philosophie Cohens, [w:] „Il Cannocchiale. Rivista di studi filosofici” 1991, Bd. 1-2: I filosofi della scuola di Marburgo.

Edel G., Von der Vernunftkritik zur Erkenntnislogik. Die Entwicklung der theoretischen Philosophie Hermann Cohens, Freiburg-München 1998.

Fichte J. G., Pierwsze wprowadzenie do teorii wiedzy, przeł. J. Garewicz, [w:] tenże, Teorie Wiedzy. Wybór pism, t. 1, przeł. M. J. Siemek, aneks przeł. J. Garewicz, Warszawa 1996.

Flach W., Das Problem der transzendentalen Deduktion: seine Exposition in der Kritik der reinen Vernunft und seine Wiederaufnahme im Neukantianismus der südwest-

${ }^{82}$ Tamże, s. 203.

${ }^{83}$ Tamże, s. 195. 
deutschen Schule, [w:] Materialien zur Neukantianismus-Diskussion, hrsg. von H.-L. Ollig, Darmstadt 1987.

Flach W., Die Objektivität der Erkenntnis, [w:] Die Aktualität der Transzendentalphilosophie. Hans Wagner zum 60. Geburtstag, hrsg. von G. Schmidt u. G. Wolandt, Bonn 1977.

Flach W., Kritizistische oder dialektische Methode? Analyse und Bewertung, [w:] Der Neukantianismus und das Erbe des deutschen Idealismus: die philosophische Methode, hrsg. von D. Pätzold u. Ch. Krijnen, Würzburg 2002.

Gilson É., Jedność doświadczenia filozoficznego, przeł. Z. Wrzeszcz, Warszawa 2001.

Hobe K., Emil Lask. Eine Untersuchung seines Denkens, Heidelberg 1968.

Kant I., Anthropologie in pragmatischer Hinsicht, [w:] Gesammelte Schriften. Akademie-Ausgabe. Bd. VII: Erste Abteilung: Werke. Siebenter Band, Berlin 1917.

Kant I., Antropologia w ujęciu pragmatycznym, przeł E. Drzazgowska, P. Sosnowska, wstęp A. Bobko. Warszawa 2005.

Kant I., Löse Blätter zu den Fortschritten der Metaphysik, [w:] tenże, Gesammelte Schriften. Akademie-Ausgabe, Bd. XX: Dritte Abteilung: Handschriftlicher Nachlaß. Siebenter Band, hrsg. von G. Lehmann, Berlin 1942.

Klein J., Die Grundlegung der Ethik in der Philosophie Hermann Cohens und Paul Natorps - eine Kritik des Neukantianismus, Göttingen 1976.

Lange F. A., Geschichte des Materialismus und Kritik seiner Bedeutung in der Gegenwart, 2. Buch: Geschichte des Materialismus seit Kant, 2. verbess. u. verm. Auflage, Iserlohn 1875.

Lübbe H., Philosophiegeschichte als Philosophie. Zu Kants Philosophiegeschichtsphilosophie, [w:] Einsichten. Gerhard Krüger zum 60. Geburtstag, hrsg. von K. Oehler u. R. Schaeffler, Frankfurt am Main 1962.

Marx W., Die philosophische Entwicklung Paul Natorps im Hinblick auf das System Hermann Cohens. In: Materialien zur Neukantianismus-Diskussion, hrsg. von H.-L. Ollig, Darmstadt 1987.

Natorp P., O obiektywnym bądź subiektywnym ugruntowaniu poznania, przeł. W. Marzęda, [w:] Neokantyzm badeński i marburski. Antologia tekstów, red. A. J. Noras, T. Kubalica, Katowice 2011.

Noras A. J., Debata Trendelenburg - Fischer. Problem obiektywności Kantowskich form zmysłowości, „Przegląd Filozoficzny - Nowa Seria” 2013, R. 22, nr 1.

Noras A. J., Emil Lask. W stulecie śmierci, „Folia Philosophica”, red. P. Łaciak, t. 33, Katowice 2015.

Noras A. J., O badaniach recepcji filozofii Kanta, „Studia z Historii Filozofii” 2014, 3(5).

Nowotniak J., Samowiedza filozofa. Johanna Gottlieba Fichtego poszukiwanie jedności, Warszawa 1995.

Paton H. J., Kant's Metaphysic of Experience. A Commentary on the First Half of the Kritik der reinen Vernunft, vol. 1, London 1936. 
Röd W., Der Weg der Philosophie von den Anfängen bis ins 20. Jahrhundert, Bd. 1: Altertum, Mittelalter, Renaissance, München 1994.

Schnädelbach H., Nasz nowy neokantyzm, przeł. A. J. Noras, „Folia Philosophica”, red. P. Łaciak, t. 24. Katowice 2006.

Tatarkiewicz W., Spór o Platona, „Przegląd Filozoficzny” 1911, R. 14, z. 3.

Winter E., Ethik und Rechtswissenschaft. Eine historisch-systematische Untersuchung zur Ethik-Konzeption des Marburger Neukantianismus im Werke Hermann Cohens, Berlin 1980.

\begin{abstract}
The Problem of Grounding of Philosophy in Hermann Cohen's Doctrine

One of the crucial elements of philosophising at the beginning of the twentieth century is the problem of grounding of philosophy. Representatives of neoKantianism fit in with this trend. They try to describe the grounding of philosophy by referring to the philosophy of Kant. That, however, raises a number of difficulties of interpretation that result from the appearing possibilities of interpretation. The article is an attempt to show the efforts of Hermann Cohen, who emphasized the importance of transcendental deduction and transcendental apperception in Kant's system. In accordance with the thesis of Fichte, Cohen searches for a basis that would allow building a system of knowledge and finds it is the concept of hypothesis.
\end{abstract}

Key words: grounding, transcendental idealism, Hermann Cohen, transcendental deduction 